\title{
Synthesis, Characterisation and Vasolidation Properties of Indanone-based Chalcones
}

\author{
Mohamad Syahir Mohd Sabri, ${ }^{1 *}$ Oo Chuan $\mathrm{Wei}^{1}$ and Yam Mun Fei ${ }^{2}$ \\ ${ }^{1}$ School of Chemical Sciences, Universiti Sains Malaysia, \\ 11800 USM Pulau Pinang, Malaysia \\ ${ }^{2}$ School of Pharmaceutical Sciences, Universiti Sains Malaysia, \\ 11800 USM Pulau Pinang, Malaysia \\ *Corresponding author: m.syahirsabri@gmail.com
}

Published online: 25 February 2018

To cite this article: Mohd Sabri, M. S., Oo, C. W. \& Yam, M. F. (2018). Synthesis, characterisation and vasolidation properties of indanone-based chalcones. J. Phys. Sci., 29(Supp. 1), 99-106, https://doi.org/10.21315/jps2018.29.s1.13

To link to this article: https://doi.org/10.21315/jps2018.29.s1.13

\begin{abstract}
Six indanone-based chalcones were successfully synthesised from 1-indanone and 4-benzaldehyde derivatives via Claisen-Schmidt condensation reaction. The synthesised indanone-based chalcones were characterised by CHN elemental analysis, FTIR spectroscopy and NMR spectroscopy to determine their structures. Vasodilation studies indicated compounds $1 \mathrm{bl}$ and $1-\mathrm{OH}$ showed good vasodilation properties with $R_{\max }$ value of $38.34 \pm 8.90 \%$ and $96.68 \pm 14.77 \%$, respectively. Compound with hydroxyl group shows better effect to the relaxation of the aortic rings.
\end{abstract}

Keywords: Chalcone, indanone, vasodilation, indanne-based chalcones, hydroxyl group

\section{INTRODUCTION}

Chalcone is a class of flavonoid consisting of two aromatic rings linked by a three carbon of $\alpha, \beta$-unsaturated carbonyl system. Other names for chalcone include benzylideneacetophenone, phenyl styryl ketone and benzalacetophenone. It is a natural pigment commonly found in most plants and is considered a vital intermediate precursor of various synthesis of flavonoids and isoflavonoids such as pyrazolines, pyrimidine, flavanol, flavones, flavanones, isoflavone, aurones, antocianidin, dihydroflavanol and dihydrochalcone. ${ }^{1}$

Studies have shown that chalcone compounds, either naturally occurring or synthetic, have a wide range of biological activities such as anticancer, antiviral, 
antimalarial, antibacterial, antifungal, anti-inflammatory and vasorelaxation properties. ${ }^{2-8}$ Chalcone is also a multifunctional molecule in which one chalcone compound can show many biological activities. One of them is Licochalcone A which shows antimalarial, anticancer, antibacterial and antiviral properties..$^{9-10}$ Also, some chalcones also interact with the anti-inflammation pathways in the cell giving them anti-inflammatory properties and consequently makes them a good candidate for treating cardiovascular diseases such as hypertension. ${ }^{8}$ Some of chalcones such as tinctormine, desmethylxanthohumol, safflower yellow and 2-(2-dimethylaminoethoxy)-3',4',5'-trimethoxychalcone has been reported to have vasodilation properties when tested with rats and dogs. ${ }^{10-14}$

In this study, several indanone-based chalcones were synthesised from indanone and benzaldehyde derivatives and were tested for their vasorelaxation properties on the aortic rings of Sprague-Dawley rats. To the best of our knowledge, this was the first vasodilation study using the synthesised indanone-based chalcones.

\section{EXPERIMENTAL}

\subsection{Materials and Instruments}

All chemicals and solvents were purchased from commercial sources and were used as received. Thin layer chromatography (TLC) analysis was carried out using aluminium-backed silica gel 60 F254 plates. UV light and iodine chamber were used to visualise the spot of the compound. Elemental analysis (CHN) was carried out on a Perkin Elmer Series II, 2400 microanalyser. Fourier transform infrared (FTIR) spectra were recorded using a Perkin Elmer 2000-FTIR spectrophotometer in the range of 4000 to $600 \mathrm{~cm}^{-1}$. Nuclear magnetic resonance (NMR) spectra were recorded using Bruker AC $500 \mathrm{MHz}$ with d6-DMSO as the solvent and TMS as an internal standard. ${ }^{1} \mathrm{H}$ and ${ }^{13} \mathrm{C}$ NMR peaks were labelled as singlet (s), doublet $(d)$, triplet $(\mathrm{t})$, and multiplet $(\mathrm{m})$. Chemical shifts were referenced with respect to solvent signals.

\subsection{Synthesis of Indanone-based Chalcones}

1-Indanone $(1.32 \mathrm{~g}, 0.01 \mathrm{~mol})$ and 1 equivalent of substituted benzaldehyde at para position were dissolved in methanol $(10 \mathrm{ml})$. Catalytic amount of piperidene was added and the mixture was refluxed at $75^{\circ} \mathrm{C}-85^{\circ} \mathrm{C}$ for $12 \mathrm{~h} .{ }^{15}$ Then the heat was turned off and the reaction mixture was left to cool. The precipitate formed was then filtered and washed with cold methanol. Then the crude product was recrystallised from ethanol. The reaction can be represented in Scheme 1. 


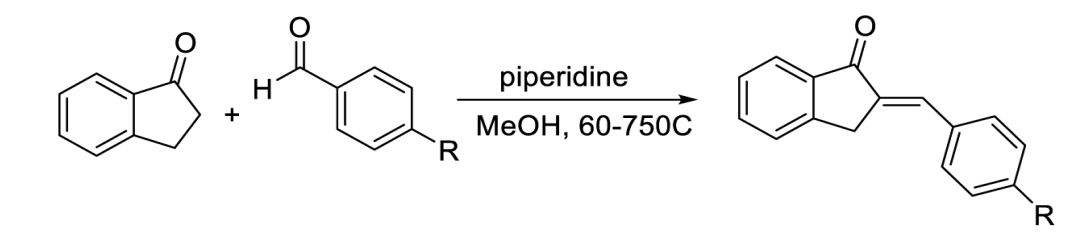

$\mathrm{R}=\mathrm{OC}_{2} \mathrm{H}_{5}(\mathbf{1 b} 1), \mathrm{OC}_{4} \mathrm{H}_{9}(\mathbf{1 b 2}), \mathrm{OC}_{6} \mathrm{H}_{13}(\mathbf{b} 3), \mathrm{OH}(1-\mathrm{OH}), \mathrm{NO}_{2}$ (1-NO2), $\mathrm{Cl}(1-\mathrm{Cl})$

Scheme 1: Synthesis of indanone-based chalcones.

\section{(E)-2-(4-ethoxybenzylidene)-2,3-dihydro-1H-inden-1-one (1b1)}

Yield $=2.19 \mathrm{~g}(83.0 \%), \mathrm{mp}: 123-124^{\circ} \mathrm{C}$, pale yellow crystal. IR $\left(\mathrm{cm}^{-1}\right): 3045$ (Csp ${ }^{2}$-H stretching), 2977 and 2936 (Csp $p^{3}-\mathrm{H}$ stretching), 1680 (C=O stretching), 1597 ( $\mathrm{C}=\mathrm{C}$ stretching), 1253 (C-O stretching). ${ }^{1} \mathbf{H}-\mathbf{N M R}$ (500 MHz, DMSO-d ( $\left._{\mathbf{6}}\right)$ $\delta$, ppm: $7.78(\mathrm{~d}, J=10.0 \mathrm{~Hz}, 1 \mathrm{H}), 7.75(\mathrm{~d}, J=10.0 \mathrm{~Hz}, 2 \mathrm{H}), 7.71 \quad(\mathrm{t}, J=7.5 \mathrm{~Hz}$, $1 \mathrm{H}), 7.69(\mathrm{t}, J=7.5 \mathrm{~Hz}, 1 \mathrm{H}), 7.52(\mathrm{~s}, 1 \mathrm{H}), 7.48(\mathrm{t}, J=5.0 \mathrm{~Hz}, 1 \mathrm{H}), 7.06(\mathrm{~d}, J=10.0$ $\mathrm{Hz}, 2 \mathrm{H}), 4.09-4.13(\mathrm{~m}, 2 \mathrm{H}) 4.08(\mathrm{~s}, 2 \mathrm{H}), 1.36(\mathrm{t}, J=5.0 \mathrm{~Hz}, 3 \mathrm{H}) .{ }^{13} \mathbf{C}-\mathbf{N M R}$ (125 MHz, DMSO-d $\left.)_{6}\right) \delta$, ppm: 193.24, 159.92, 149.82, 137.45, 134.58, 132.86, $132.70,132.46,127.59,127.33,126.61,123.43,114.97,63.34,31.89,14.50$. CHN elemental analysis: Calculated for $\mathrm{C}_{18} \mathrm{H}_{16} \mathrm{O}_{2}: \mathrm{C}: 81.79 \%, \mathrm{H}: 6.10 \%$. Found: $\mathrm{C}$ : $81.23 \%$, H: $6.11 \%$.

\section{(E)-2-(4-butoxybenzylidene)-2,3-dihydro-1H-inden-1-one (1b2)}

Yield $=2.19 \mathrm{~g}(75.0 \%), \mathrm{mp}: 121-122^{\circ} \mathrm{C}$, white crystal. IR $\left(\mathbf{c m}^{-1}\right): 3052\left(\mathrm{Csp}^{2}-\mathrm{H}\right.$ stretching), 2949 and 2869 (Csp $p^{3}-\mathrm{H}$ stretching), 1696 (C=O stretching), $1598(\mathrm{C}=\mathrm{C}$ stretching), 1241 (C-O stretching). ${ }^{1} \mathbf{H}-\mathbf{N M R}\left(\mathbf{5 0 0} \mathbf{~ M H z}\right.$, DMSO-d $\left._{6}\right) \delta$, ppm: 7.79 (d, $J=5.0 \mathrm{~Hz}, 1 \mathrm{H}), 7.75$ (d, $J=10.0 \mathrm{~Hz}, 2 \mathrm{H}), 7.71(\mathrm{t}, J=5.0 \mathrm{~Hz}, 1 \mathrm{H}), 7.69$ (t, $J=5.0$ $\mathrm{Hz}, 1 \mathrm{H}), 7.52$ (s, 1H), 7.48 (t, $J=7.5 \mathrm{~Hz}, 1 \mathrm{H}), 7.07$ (d, $J=10.0 \mathrm{~Hz}, 2 \mathrm{H}), 4.09$ (s, 2H), $4.05(\mathrm{t}, J=5.0 \mathrm{~Hz}, 2 \mathrm{H}), 1.70-1.76(\mathrm{~m}, 2 \mathrm{H}), 1.42-1.50(\mathrm{~m}, 2 \mathrm{H}), 0.95(\mathrm{t}, J=7.5 \mathrm{~Hz}$, 3H). ${ }^{13}$ C-NMR (125 MHz, DMSO-d $\left.{ }_{6}\right) \delta$, ppm: 193.23, 160.11, 149.83, 137.46, $134.59,132.87,132.70,132.46,127.60,127.33,126.62,123.44,115.01,67.39$, 31.90, 30.60, 18.67, 13.64. CHN elemental analysis: Calculated for $\mathrm{C}_{20} \mathrm{H}_{20} \mathrm{O}_{2}$ : C: $82.16 \%$, H: $6.90 \%$. Found: C: $82.05 \%$, H: $6.87 \%$.

\section{(E)-2-(4-(hexyloxy)benzylidene)-2,3-dihydro-1H-inden-1-one (1b3)}

Yield $=2.43 \mathrm{~g}(76.0 \%), \mathrm{mp}: 117-119^{\circ} \mathrm{C}$, yellow crystal. IR $\left(\mathbf{c m}^{-1}\right): 2958\left(\mathrm{Csp} p^{2}-\mathrm{H}\right.$ stretching), 2931 and 2851 (Csp $p^{3}-\mathrm{H}$ stretching), 1691 (C=O stretching), $1595(\mathrm{C}=\mathrm{C}$ stretching), 1253 (C-O stretching). ${ }^{1} \mathbf{H}-\mathbf{N M R}\left(\mathbf{5 0 0} \mathbf{~ M H z}\right.$, DMSO-d $\left.\mathbf{d}_{\mathbf{6}}\right) \delta$, ppm: 7.78 (d, $J=10.0 \mathrm{~Hz}, 1 \mathrm{H}), 7.74(\mathrm{~d}, J=10.0 \mathrm{~Hz}, 2 \mathrm{H}), 7.71$ (t, $J=5.0 \mathrm{~Hz}, 1 \mathrm{H}), 7.69$ (t, $J=7.5$ $\mathrm{Hz}, 1 \mathrm{H}), 7.52(\mathrm{~s}, 1 \mathrm{H}), 7.48(\mathrm{t}, J=7.5 \mathrm{~Hz}, 1 \mathrm{H}), 7.06(\mathrm{~d}, J=10.0 \mathrm{~Hz}, 2 \mathrm{H}), 4.08(\mathrm{~s}, 2 \mathrm{H})$, $4.04(\mathrm{t}, J=7.5 \mathrm{~Hz}, 2 \mathrm{H}), 1.70-1.76(\mathrm{~m}, 2 \mathrm{H}), 1.40-1.46(\mathrm{~m}, 2 \mathrm{H}), 1.30-1.34(\mathrm{~m}, 4 \mathrm{H})$, 0.89 (t, $J=7.5 \mathrm{~Hz}, 3 \mathrm{H}) .{ }^{13} \mathbf{C}-\mathbf{N M R}\left(\mathbf{1 2 5} \mathbf{~ M H z}\right.$, DMSO-d $\left._{\mathbf{6}}\right) \delta$, ppm: 193.26, 160.10, $149.81,137.46,134.58,132.86,132.69,132.43,127.59,127.32,126.60,123.43$, 
115.00, 67.69, 31.90, 30.95, 28.51, 25.11, 22.02, 13.86. CHN elemental analysis: Calculated for $\mathrm{C}_{22} \mathrm{H}_{24} \mathrm{O}_{2}$ : C: $82.46 \%$, H: $7.55 \%$. Found: C: $82.51 \%$, H: $7.57 \%$.

(E)-2-(4-hydroxybenzylidene)-2,3-dihydro-1H-inden-1-one (1-OH) Yield $=2.00 \mathrm{~g}(85.0 \%)$, mp: $223-225^{\circ} \mathrm{C}$, bright yellow crystal. IR $\left(\mathbf{c m}^{-\mathbf{1}}\right): 3114$ (O-H stretching) 2897 (Csp ${ }^{2}-\mathrm{H}$ stretching), $1673(\mathrm{C}=\mathrm{O}$ stretching), $1595(\mathrm{C}=\mathrm{C}$ stretching). ${ }^{1} \mathbf{H}-\mathbf{N M R}$ (500 MHz, DMSO-d ) $\delta$, ppm: 7.77 (d, $\left.J=10.0 \mathrm{~Hz}, 1 \mathrm{H}\right)$, 7.65-7.71 (m, 4H), 7.46-7.49 (m, 2H), 6.91 (d, J=5.0 Hz, 2H), $4.06(\mathrm{~s}, 2 \mathrm{H})$, ${ }^{13}$ C-NMR (125 MHz, DMSO-d 6 ) $\delta$, ppm: 193.22, 159.42, 149.77, 137.57, 134.46, $133.33,132.95,131.52,127.56,126.57,125.96,123.38,116.03,31.94 . \mathbf{C H N}$ elemental analysis: Calculated for $\mathrm{C}_{16} \mathrm{H}_{12} \mathrm{O}_{2}: \mathrm{C}: 81.34 \%, \mathrm{H}: 5.12 \%$. Found: $\mathrm{C}$ : $81.38 \%$, H: 5.14\%.

(E)-2-(4-nitrobenzylidene)-2,3-dihydro-1H-inden-1-one (1-NO2)

Yield $=2.39 \mathrm{~g}(90.0 \%)$, mp: $240-243^{\circ} \mathrm{C}$, yellow crystal. IR $\left(\mathbf{c m}^{-\mathbf{1}}\right): 3077\left(\mathrm{Csp}{ }^{2}-\mathrm{H}\right.$ stretching), 1691 ( $\mathrm{C}=\mathrm{O}$ stretching), $1506(\mathrm{C}=\mathrm{C}$ stretching), 1335 (C-N stretching). ${ }^{1}$ H-NMR (500 MHz, DMSO-d 6 ) $\delta$, ppm: 8.30 (d, $J=10.0$ Hz, 2H), 8.01 (d, $J=5.0$ $\mathrm{Hz}, 2 \mathrm{H}), 7.83$ (d, J=5.0 Hz, 1H), 7.69-7.42 (m, 2H), 7.64 (s, 1H), 7.51 (t, J=7.5 Hz, 1H), 4.18 (s, 2H). ${ }^{13}$ C-NMR (125 MHz, DMSO-d $\left.)_{6}\right) \delta$, ppm: 192.73, 149.94, $141.55,139.11,137.10,135.11,131.29,130.03,127.77,126.57,123.73,123.65$, 31.74. CHN elemental analysis: Calculated for $\mathrm{C}_{16} \mathrm{H}_{11} \mathrm{NO}_{3}: \mathrm{C}: 72.45 \%, \mathrm{H}: 4.18 \%$ N: $5.28 \%$. Found: C: $72.39 \%, H: 4.16 \%, \mathrm{~N}: 5.27 \%$.

\section{(E)-2-(4-chlorobenzylidene)-2,3-dihydro-1H-inden-1-one (1-Cl)}

Yield $=1.98 \mathrm{~g}(78.0 \%)$, mp: $178-180^{\circ} \mathrm{C}$, white crystal. IR $\left(\mathbf{c m}^{-1}\right): 3029\left(\mathrm{Csp}{ }^{2}-\mathrm{H}\right.$ stretching), 1691 ( $\mathrm{C}=\mathrm{O}$ stretching), 1602 ( $\mathrm{C}=\mathrm{C}$ stretching), 819 (C-Cl stretching). ${ }^{1}$ H-NMR (500 MHz, DMSO-d $)^{\text {) }} \delta$, ppm: 7.81 (t, $\left.J=10.0 \mathrm{~Hz}, 3 \mathrm{H}\right), 7.73$ (t, $J=7.5$ $\mathrm{Hz}, 1 \mathrm{H}), 7.68$ (d, $J=10.0 \mathrm{~Hz}, 1 \mathrm{H}), 7.57$ (d, $J=10.0 \mathrm{~Hz}, 2 \mathrm{H}), 7.54$ (s, 1H), 7.49 (t, $J=7.5 \mathrm{~Hz}, 1 \mathrm{H}), 4.12$ (s, 2H). ${ }^{13}$ C-NMR (125 MHz, DMSO-d $\left.)_{6}\right) \delta$, ppm: 193.22, $149.99,137.07,135.76,133.02,134.41,133.77,132.34,131.38,128.99,127.73$, 126.67, 123.64, 31.77. CHN elemental analysis: Calculated for $\mathrm{C}_{16} \mathrm{H}_{11} \mathrm{ClO}$ : $\mathrm{C}$ : 75.45\%, H: 4.35\%. Found: C: $75.39 \%, \mathrm{H}: 4.33 \%$.

\subsection{Evaluation of Vasodilation Activity}

Vascular rings were prepared from the aorta of male Sprague-Dawley rats with average weight of $250 \mathrm{~g}$. To validate the condition of the aortic ring's endothelium, the aortic rings were pre-contracted with phenylephrine (PE, $1 \mu \mathrm{M})$, followed by relaxation with acetylcholine $(\mathrm{Ach}, 1 \mu \mathrm{M})$. After that, the aortic rings were rinsed with Kreb's solution and the tension was adjusted back to the baseline of $1 \mathrm{~g}$. Then $1 \mu \mathrm{M}$ of PE was added to establish a stable contractile tone. Subsequent concentration of the compound which was dissolved in water was added into the 
organ bath at $20 \mathrm{~min}$ interval. Changes of the contractile force were measured with a force transducer (GRASS Force-Displacement Transducer FT03, UK). The signals were read by using Labchart-7 and the data was tabulated using Microsoft Excel.

(a)

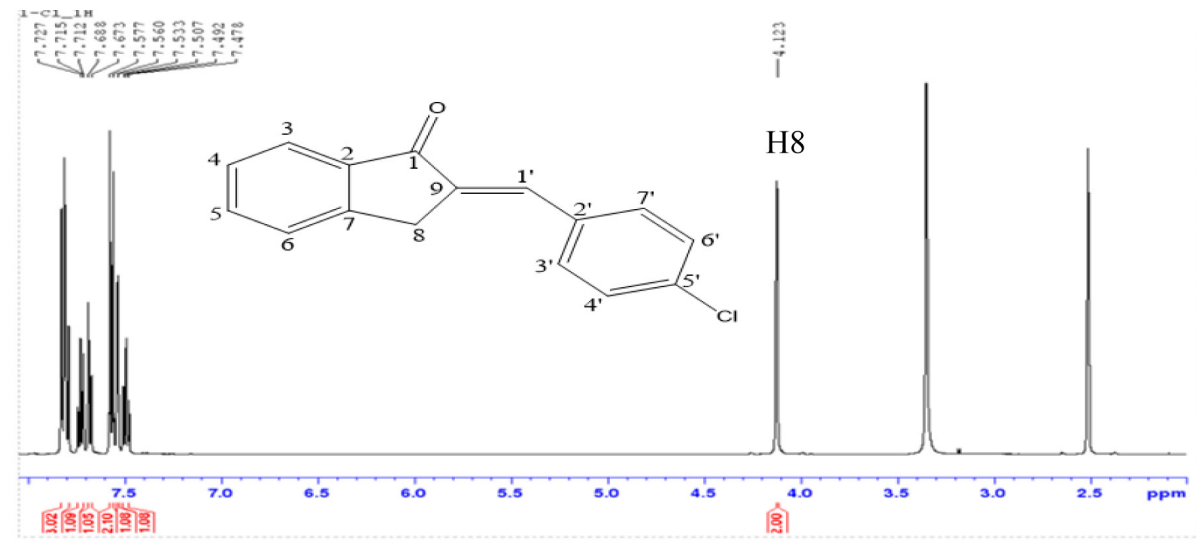

(b)

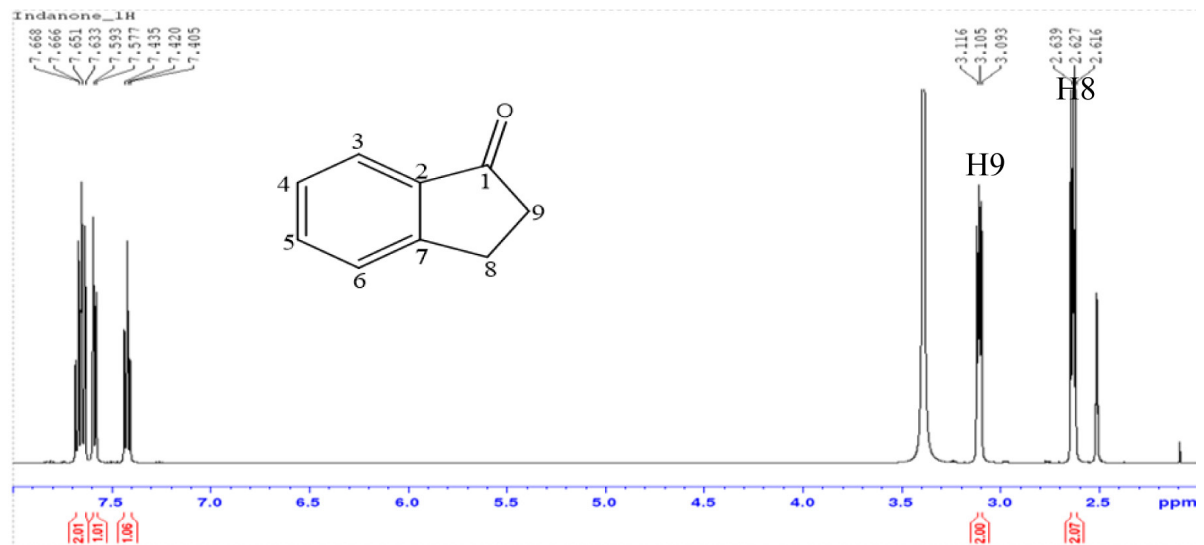

Figure 1: ${ }^{1} \mathrm{H}$ NMR spectra of indanone-based chalcone, 1-Cl (a) and indanone (b).

\section{RESULTS AND DISCUSSION}

\subsection{Spectroscopic Studies}

In the ${ }^{1} \mathrm{H}$ NMR spectrum of the synthesised indanone-based chalcone, 1-Cl (Figure 1a), the sharp singlet that appeared at the downfield region, $\delta 7.54 \mathrm{ppm}$ was attributed to the $-\mathrm{C}=\mathrm{CH}$ proton that formed from the condensation of indanone with benzaldehyde. The methylene protons (H8) on the indanone rings of 1-Cl was observed, $\delta 4.12 \mathrm{ppm}$. Triplet corresponding to the methylene protons (H9) 
in indanone (as shown in Figure 1b) disappeared, indicated the formation of $\mathrm{C}=\mathrm{C}$ from the condensation. In the NMR spectra for $\mathbf{1 b 1 - 1 b 3}$ peaks in the upfield regions referred to the aliphatic protons. In the ${ }^{13} \mathrm{C}$ NMR spectra, all products showed similar trend of signals and number of carbon atoms were corresponding to the structures. For the indanone-based chalcones, the peaks for carbonyl carbon appeared around $\delta 193.00 \mathrm{ppm}$ while the peak for the $\mathrm{C} 8$ appeared around $\delta 32.00$ $\mathrm{ppm}$. In the IR spectra, the band for $\mathrm{C}=\mathrm{O}$ functional groups was in between 1680 $1700 \mathrm{~cm}^{-1}$. Bands at the region of $1520-1625 \mathrm{~cm}^{-1}$ were for $\mathrm{C}=\mathrm{C}$ functional groups.

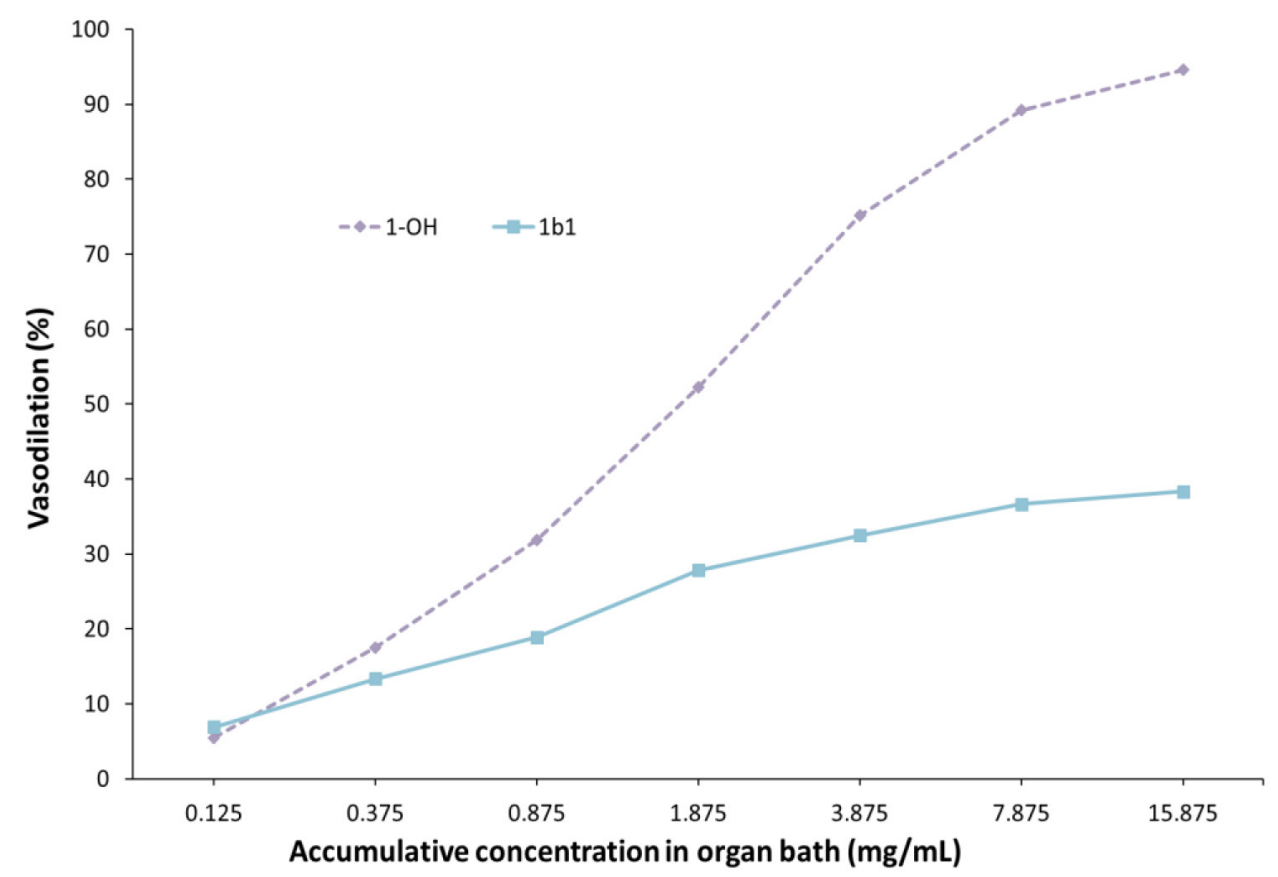

Figure 2: Effects of indanone-based chalcones $\mathbf{1 - O H}$ and $\mathbf{1 - C l}$ on relaxation in aortic rings.

\subsection{Vasodilation Studies}

Before starting the studies, the synthesised indanone-based chalcones were tested for their solubility in water. Tween 80 was used as surfactant to increase the solubility of the chalcones in water and the best compounds $\mathbf{1 b 1}$ and $\mathbf{1 - O H}$ that fully dissolved were used in the vasodilation studies. The other compounds 1b2, 1b3, 1-OH, 1-NO2, and 1-Cl, however, were undissolved and could not be investigated. Compound $\mathbf{1 b 1}$ showed maximal relaxation $\left(\mathrm{R}_{\max }\right)$ value of $38.34 \pm$ $8.90 \%$. Meanwhile compound 1-OH showed greater effect on the vasorelaxant activities with highest $\mathrm{R}_{\max }$ value of $96.68 \pm 14.77 \%$ (Figure 2 ). The greater potency 
of 1-OH can be attributed to the present of hydroxyl group in the compound. ${ }^{8}$ There are few pathways that might be involved in vasodilation of blood vessel caused by compound $\mathbf{1 b 1}$ and 1-OH such as endothelium-dependent or non-dependent pathways, potassium and calcium channels, muscarinic and $\beta$-adrenergic receptors. Further investigation is needed to confirm the type of mechanism pathway of these chalcones.

\section{CONCLUSION}

All the compounds 1b1-1b3, 1-OH, 1-NO2 and 1-Cl were successfully synthesised and characterised. From the spectroscopic data, the formation of indanone-based chalcones was successful. The tested chalcones for vasorelaxant properties showed good results and further studies are needed to find the inhibition mechanism of the chalcones that caused the cells in the aortic ring to relax.

\section{REFERENCES}

1. Wong, E. (1968). The role of chalcones in flavanones biosynthesis. Phytochem., 7, 1751-1758, https://doi.org/10.1016/S0031-9422(00)86646-7.

2. Zengin Kurt, B. et al. (2017). Synthesis and biological evaluation of novel coumarin-chalcone derivatives containing urea moiety as potential anticancer agents. Arab. J. Chem., 1-10.

3. Cabral, B. L. S. et al. (2017). A novel chalcone derivative, LQFM064, induces breast cancer cells death via p53, p21, KIT and PDGFRA. Eur. J. Pharm. Sci., 107, 1-15, https://doi.org/10.1016/j.ejps.2017.06.018.

4. Wang, Y. J. et al. (2017). Synthesis and antiviral bioactivity of novel chalcone derivatives containing purine moiety. Chin. Chem. Lett., 7-10, https://doi. org/10.1016/j.cclet.2017.07.006.

5. Domínguez, J. N. et al. (2005). Synthesis and antimalarial activity of sulfonamide chalcone derivatives. Farmaco, 60(4), 307-311, https://doi. org/10.1016/j.farmac.2005.01.005.

6. Gómez-Rivera, A. et al. (2013). Synthesis and anti-inflammatory activity of three nitro chalcones. Bioorg. Med. Chem. Lett., 23(20), 5519-5522, https://doi.org/10.1016/j.bmcl.2013.08.061.

7. Khan, S. A. \& Asiri, A. M. (2017). Green synthesis, characterization and biological evaluation of novel chalcones as anti bacterial agents. Arab. J. Chem., 10, S2890-S2895, https://doi.org/10.1016/j.arabjc.2013.11.018.

8. Dong, X. et al. (2009). Design, synthesis, and biological evaluation of prenylated chalcones as vasorelaxant agents. Arch. der Pharm., 342(7), 428-432, https://doi.org/10.1002/ardp.200800229. 
9. Chen, M. et al. (1994). Licochalcone A, a new antimalarial agent, inhibits in vitro growth of the human malaria parasite Plasmodium falciparum and protects mice from P. yoelii infection. Antimicrob. Agents Chem., 38(7), 1470-1475, https://doi.org/10.1128/AAC.38.7.1470.

10. Zhang, Y. et al. (2016). Licochalcone A exerts antitumor activity in bladder cancer cell lines and mice models. Trop. J. Pharm., 15(6), 1151-1157, https://doi.org/10.4314/tjpr.v15i6.6.

11. Liu, F. et al. (1992). Hypotensive effects of safflower yellow in spontaneously hypertensive rats and influence on plasma renin activity and angiotensin II level. Yao XиeXиeBao, 27(10), 785-787.

12. Meselhy, M. R. et al. (1993). Two new quinochalcone yellow pigments from Carthamus tinctorius and $\mathrm{Ca} 2+$ antagonistic activity of tinctormine. Chem. Pharm. Bull., 41(10), 1796-1802, https://doi.org/10.1248/cpb.41.1796.

13. Dong, X. et al. (2009). Design, synthesis, and biological evaluation of prenylated chalcones as vasorelaxant agents. Arch. Pharm. Chem. Life Sci., 342, 428-432, https://doi.org/10.1002/ardp.200800229.

14. Sherman, G. P. et al. (1968). Electrolyte alterations in vascular smooth muscle and hypotensive activity of a new chalcone derivative. J. Pharm. Sci., 57 (5), 733-737, https://doi.org/10.1002/jps.2600570502.

15. Bhasker, N., Prashanthi, Y. \& Subba Reddy, B. V. (2015). Piperidine mediated synthesis of new series of prenyloxy chalcones, flavanones and comparative cytotoxic study. Der Pharm. Lett., 7(1), 8-13. 